\title{
Angiotensin-Converting Enzyme Inhibitor Induced Cough in Chinese Patients: a Systematic Review and Meta-analysis
}

\author{
Ling Liang ${ }^{1,2}$, Janice Y. Kung ${ }^{3}$, Bradley Mitchelmore ${ }^{4}$, Jasmine Gill ${ }^{5}$, Andrew Cave ${ }^{6}$, and Hoan Linh Banh ${ }^{6}$ \\ ${ }^{1}$ Department of Cardiology, The First Affiliated Hospital of Xiamen University, Xiamen, China; ${ }^{2}$ Department of \\ Cardiology, First Clinical Medical College of Fujian Medical University, Fuzhou, China; ${ }^{3}$ University of Alberta, John W. \\ Scott Health Sciences Library; ${ }^{4}$ Public Health Agency of Canada; ${ }^{5}$ University of Alberta Hospital, Department of \\ Pharmacy, Faculty of Pharmacy and Pharmaceutical Sciences, University of Alberta; ${ }^{6}$ University of Alberta, Faculty of \\ Medicine and Dentistry, Department of Family Medicine.
}

Corresponding authors: Ling Liang, M.D., Department of Cardiology, The First Affiliated Hospital of Xiamen University, No 55 Zhenhai Road, Xiamen, China, 361000; TEL.: (+86)13860129351; fax: +(86)0592-2181680; email: ravennaliang@ sina.com; Hoan Linh Banh, Pharm.D., Faculty of Medicine and Dentistry/Department of Family Medicine, University of Alberta; 6-10 University Terrace, Edmonton, AB, T6G 2C8, Canada; email: hoan@ualberta.ca

Received, December 10, 2020; Revised, March 3, 2021; Accepted, March 16, 2021; Published, March 18, 2021

\begin{abstract}
Purpose: To determine the risk of angiotensin converting enzyme inhibitor (ACEI)-induced cough compared to non-ACEI cough among Chinese patients. Methods: A comprehensive search was conducted including randomized controlled trials, case-control studies and observational studies that compared ACEI treatment with control treatment in MEDLINE, EMBASE, CINAHL, Scopus, Google Scholar and ProQuest Dissertations \& Theses Global. The studies which contained: Chinese population, ACEI, non-ACEI, and indications for the treatment of ACEI were included. The pooled risk ratios (RRs) and $95 \%$ confidence intervals (CIs) were calculated to compare the relative risk of cough between ACEIs and non-ACEI drugs based on the events of reported cough in each study. Results: Eleven randomized controlled trials were included with a total of 1815 patients. The total number of cough events in ACEI treatment was 101 in 930 patients $(11 \%)$ and 20 in 885 patients $(2 \%)$ in the Non-ACEI treatment. The pooled RR was 5.16 (95\% CI: 3.39-7.85) under fixed model. The discontinuation number of single ACEI treatment due to coughing side effect was 21 and the withdrawal rate was $4.13 \%$. Only two patients discontinued non-ACEIs treatment due to the intolerable cough and the withdrawal rate was $0.34 \%$. The overall RR of withdrawal related to cough was 7.06 (95\% CI: 2.49-20.04). Conclusions: The pooled risk of the incidence of ACEI-induced cough was about five times higher than that of non-ACEI-induced cough in Chinese population. The risk of withdrawal events related to cough in the single ACEI treatment was seven times of that in the non-ACEI treatment.
\end{abstract}

\section{INTRODUCTION}

According to the World Health Organization, almost 18 million (31\%) of people who died in the world in 2008, died from cardiovascular diseases (CVD) and by 2030, approximately 24 million people will die from CVD (1). Angiotensinconverting enzyme inhibitors (ACEI) are cornerstones of treatment for CVD such as hypertension, heart failure and myocardial infarction. They have been shown to reduce mortality and morbidity in patients with cardiovascular diseases (2-7). ACEI-induced cough is one of the most commonly reported adverse effects of the treatment. However, the prevalence of ACEI-induced cough in Chinese patients is higher than that of the other populations. In one study the incidence of cough has been reported to be $5 \%$ to $35 \%$ (8). In North America (9) on the other hand, the reported incidence of ACEIinduced cough in Chinese patients varies from 5\% to $29 \%$ (10). The primary objective of this systematic review and meta-analysis is to identify the incidence of ACEI-induced cough in Chinese patients. The secondary objective is to determine the risk of ACEI induced cough in Chinese patients.

\section{METHOD}

This systematic review was performed in accordance with the checklist of Preferred Reporting Items for Systematic Review and MetaAnalyses (PRISMA) statement (11).

\section{Search strategy}

The medical librarian conducted comprehensive searches which included all randomized controlled trials, case-control studies and observational studies available in English that compared active treatment with ACEI or control treatment (placebo, active control, or usual care) in MEDLINE (via 
Ovid), EMBASE (Ovid), CINAHL, Scopus, Google Scholar and ProQuest Dissertations \& Theses Global from inception to February 15, 2019. A diverse range of keywords and controlled vocabulary including: "angiotensin converting enzyme inhibitors", "ACEI", "ACE inhibitor", "cough", "Chinese", and all the possible individual ACEI generic names was used (supplemental table). A total of 293 results were retrieved, with 137 unique results remaining for title and abstract screening after exclusions. In addition to searching subscription databases, the research team reviewed the first 100 results of a Google Scholar search. Bibliographies from included studies were also examined and such studies were considered for inclusion. After screening of abstracts, 58 studies were identified. Eight duplicates, eight studies in Chinese, and six studies not retrievable despite contacting the authors were excluded. After review of complete articles, only 11 studies satisfied the inclusion and exclusion criteria (Figure 1).

\section{Data extraction and quality assessment}

The searches were independently conducted by two authors (HLB, JG). Disagreements were resolved by a third author (AC). The data were independently extracted by two authors (LL, HLB). This included: demographic characteristics, authors, journal, population, intervention, comparator, sample size and drug related cough events. The meta-analysis consists of randomized controlled studies with the following inclusion criteria: 1) Chinese population, 2) a group treated with ACEI, 3) a group treated with non-ACEI comparator, and 4) the indications for the treatment of ACEI are hypertension, heart failure, cardiovascular disease, or stroke. Exclusion criteria were: 1) non-Chinese patients, and 2) no comparator treatment group.

For studies with insufficient information reported in trials, authors were contacted or data were calculated according to the methods in the Cochrane Handbook for Systematic Reviews of Interventions (12). To assess risk of bias in randomized trials (13), two raters independently used the Cochrane Collaboration's tools to evaluate the included risk bias of the studies. Seven bias domains in the tool were applied to assess the overall quality of the evidence as follows: random sequence generation, allocation concealment, blinding of participants and personnel, blinding of outcome assessment, incomplete outcome data, selective reporting and other bias. : In every domain, a judgment was made in one of three categories (unclear, high risk or low risk). Unclear judgment was defined as no description of incidence of outcome measured which occurred in one article, while high risk or low risk of bias was judged based on the Cochrane Handbook (13).

\section{Patient and public involvement}

Patients and carers (and respective organizations) were involved in the design and development of the program development grant application. Patients and carers attended all the steering group meetings and were an integral part of the research team, commenting on and critiquing the inclusion and exclusion criteria, outcome selection, and the acceptability and likely value of interventions. As part of the steering group, they received and commented on study progression, emergent findings and reports. They are integral to the dissemination plans, including sharing the publication, but also helping craft lay summaries of the overall research project and key findings. A public -patient representative $(\mathrm{EH})$ performed the data extraction together with research and clinical colleagues, and coauthored and edited this article. Public-patient representatives were also part of the steering group and informed the design and delivery of the article.

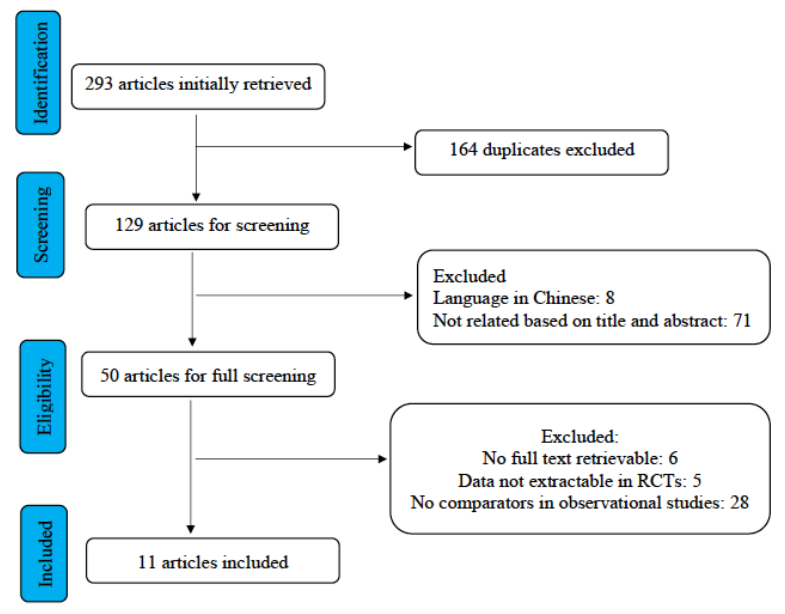

Figure 1. Search strategy

\section{STATISTICAL ANALYSIS}

The pooled estimates of risk ratios (RRs) and 95\% confidence intervals (CIs) were calculated to compare the relative risk of cough between ACEIs and non-ACEI drugs based on the events of reported cough in each study. $\mathrm{I}^{2}$ statistic was applied to inspect heterogeneity. If $\mathrm{I}^{2}$ is $<50 \%$ and $p$ value is $>0.1$, heterogeneity is acceptable. If $\mathrm{I}^{2}>$ $50 \%$ and $p$ value $<0.1$, the random effect or a metaregression method to find sources for the obvious heterogeneity was performed. The presence of small study effects was assessed by visually 
interpreting funnel plot asymmetry and quantified by Egger test $(p<0.05)$. A two-tailed $p$-value < 0.05 was considered statistically significant. All the statistical analyses were performed in Stata 14.1 (Stata Corp, College Station, TX).

\section{RESULTS}

\section{The Search Result}

A total of 293 studies were identified from the search. One hundred and sixty-four studies were duplicates and were excluded. Eight studies were in Chinese language, but the studies were not relevant to the meta-analysis and were excluded. After screening the abstracts of the studies, 71 studies were excluded as they were not related to the topic. After screening the full text of the remaining 50 studies, six studies were not retrievable, five studies have no extractable data, and 28 studies with no comparators. As a result, eleven randomized controlled trials were included (Figure 1) with a total of 1815 patients in the studies. All observational studies were excluded because they did not have a comparator group.

\section{Characteristics of the included trials}

Totally, there were eleven randomized controlled trials included in this meta-analysis paper. Three studies were placebo-controlled trials, and eight studies were head-to-head comparisons between ACEI and other alternatives such as calcium channel blockers (CCB), angiotensin receptor blocker II (ARB) and diuretics. Three trials were completed in Hong Kong, three in mainland China and five in Taiwan. Participants with moderate hypertension were enrolled in six of the studies and five studies included patients with kidney disease. The subject age ranged from 18 to 75 years. The observation period of cough induced by treatments varied from four weeks to five years. Basic characteristics of the studies are listed in Table 1 and the quality of eligible studies is shown in Figure 2. Overall study quality has low risk of bias.

\section{Cough events between ACEIs and Non-ACEIs}

Cough events were reported in the eleven trials. The total number of cough events in ACEI treatment group was 101 in 930 patients (11\%) and 20 in 885 patients $(2 \%)$ in Non-ACEI treatment group. The overall pooled estimate of relative risk ratios (RRs) was 5.16 (95\% CI: 3.39-7.85) under fixed model with no observed heterogeneity $\left(\mathrm{I}^{2}=0 \%, p=0.885\right)$ (Figure 3). The risk ratio of cough with ACEI was 4.38 times (95\% CI: 1.29 14.8) compared with Placebo treatment. Similarly, the risk ratio of cough between ACEI group and CCB group was 4.56 (95\% CI: 2.18-9.56). The highest risk ratio was 5.61 (95\% CI: 3.22-9.79) as the incidence of cough caused by ACEIs compared with ARB. The funnel plot was symmetric and Egger test $p$ value was 0.229 , meaning there is no significant publication bias and no small sample size studies effect.

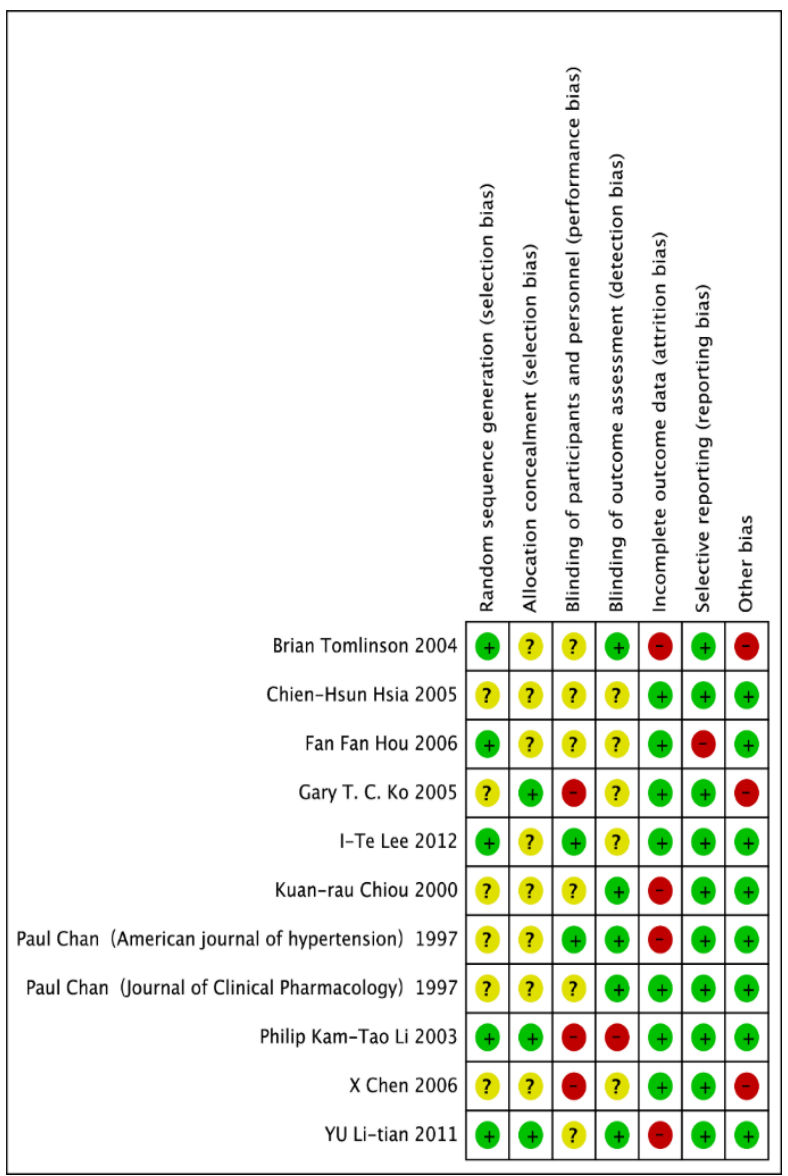

Figure 2. Bias risk assessment for the studies (yellow color: unclear risk, green color: low risk, red color: high risk.)

\section{Withdrawal events related to cough between ACEIs and Non-ACEIs}

Five trials were extracted to analyse the withdrawal events related to cough. 21 patients in 509 (4.13\%) discontinued the single ACEI treatment due to the intolerable cough, while only 2 patients developed cough in 594 patients under non-ACEIs treatment $(0.34 \%)$. The pooled risk ratio of withdrawal events due to the intolerable cough was 7.06 (95\% CI: 2.49-20.04) under fixed model. I square was $0 \%$ and the heterogeneity was undetectable $(p=0.946)$ (see Figure 4). No publication bias was observed from the symmetric funnel plot. Egger test result ( $p=0.914$ ) indicated no small sample size studies effect. 
Table 1. Basic characteristics of studies

\begin{tabular}{|c|c|c|c|c|c|c|}
\hline Study, year & Journal & Patients characteristics, sample size & ACEI drugs & Comparator drugs & $\begin{array}{l}\text { Maximal dosage of } \\
\text { ACEIs }\end{array}$ & Follow-up \\
\hline $\begin{array}{l}\text { Brian } \\
\text { Tomlinson et al } \\
2004\end{array}$ & $\begin{array}{l}\text { Clinical } \\
\text { Therapeutics }\end{array}$ & $\begin{array}{l}\text { Population : hypertension } \\
\text { Mean age (range): } 60.5 \mathrm{y} \\
80 \text { patients }(\mathrm{G} 1=40, \mathrm{G} 2=40)\end{array}$ & G1: Enalapril & G2: Amlodipine & $20 \mathrm{mg}$ & 14 weeks \\
\hline $\begin{array}{l}\text { Chien-Hsun } \\
\text { Hsia et al } \\
2005\end{array}$ & $\begin{array}{l}\text { Acta Cardiologica } \\
\text { Sinica }\end{array}$ & $\begin{array}{l}\text { Population : hypertension } \\
\text { Mean age (range): } 18-75 y \\
50 \text { patients }(\mathrm{G} 1=26, \mathrm{G} 2=24)\end{array}$ & G1:Perindopril/ indapamide & G2: Losartan & $4 / 1.25 \mathrm{mg}$ & 12 weeks \\
\hline $\begin{array}{l}\text { Fan Fan Hou et } \\
\text { al } 2006\end{array}$ & $\begin{array}{l}\text { New England } \\
\text { Journal of Medicine }\end{array}$ & $\begin{array}{l}\text { Population : chronic kidney disease } \\
\text { Mean age (range): } 18-70 \mathrm{y} \\
328 \text { patients(G1=216,G2=112) }\end{array}$ & G1: Benazepril & G2: Placebo & $20 \mathrm{mg}$ & 4 weeks \\
\hline $\begin{array}{l}\text { Gary T. C. Ko } \\
\text { et al } 2005\end{array}$ & $\begin{array}{l}\text { Advances in } \\
\text { Therapy }\end{array}$ & $\begin{array}{l}\text { Population : type } 2 \text { diabetes and normal renal function } \\
\text { or early-stage nephropathy } \\
\text { Mean age (range): } 61 \mathrm{y} \\
42 \text { patients }(\mathrm{G} 1=20, \mathrm{G} 2=22)\end{array}$ & G1: Enalapril & G2: Valsartan & $10 \mathrm{mg}$ & 52 weeks \\
\hline $\begin{array}{l}\text { I-Te Lee et al } \\
2012\end{array}$ & $\begin{array}{l}\text { Clinical } \\
\text { Therapeutics }\end{array}$ & $\begin{array}{l}\text { Population : hypertension patients with } \\
\text { microalbuminuria } \\
\text { Mean age (range): } 59.7 y \\
167 \text { patients(G1 }=83, \mathrm{G} 2=84)\end{array}$ & G1: Amlodipine/Benazepril & G2:Valsartan/hydrochlorothiazide & $5 / 10 \mathrm{mg}$ & 16 weeks \\
\hline $\begin{array}{l}\text { Kuan-Rau } \\
\text { Chiou et al } \\
2000\end{array}$ & $\begin{array}{l}\text { Chinese Medical } \\
\text { Journal }\end{array}$ & $\begin{array}{l}\text { Population : hypertension } \\
\text { Mean age (range): } 53.2 \mathrm{y} \\
68 \text { patients }(\mathrm{G} 1=34, \mathrm{G} 2=34)\end{array}$ & G1: Enalapril & G2: Irbesartan & $20 \mathrm{mg}$ & 8 weeks \\
\hline $\begin{array}{l}\text { Paul Chan et al } \\
1997\end{array}$ & $\begin{array}{l}\text { American journal of } \\
\text { hypertension }\end{array}$ & $\begin{array}{l}\text { Population : hypertension } \\
\text { Mean age (range): } 65 \mathrm{y} \\
156 \text { patients(G1=52,G2=26,G3=51,G4=27) }\end{array}$ & $\begin{array}{l}\text { G1: Lisinopril + Diltiazem } \\
\text { G2: Lisinopril + Placebo }\end{array}$ & $\begin{array}{l}\text { G3: Diltiazem+ placebo } \\
\text { G4: Placebo+ placebo }\end{array}$ & $10 \mathrm{mg}$ & 12 weeks \\
\hline $\begin{array}{l}\text { Paul Chan et al } \\
1997\end{array}$ & $\begin{array}{l}\text { Journal of Clinical } \\
\text { Pharmacology }\end{array}$ & $\begin{array}{l}\text { Population : hypertension } \\
\text { Mean age (range): } 73 y \\
84 \text { patients(G1=28,G2=28,G3=28) }\end{array}$ & G1: Lisinopril & $\begin{array}{l}\text { G2: Metolazone } \\
\text { G3: Losartan }\end{array}$ & $10 \mathrm{mg}$ & 10 weeks \\
\hline $\begin{array}{l}\text { Philip Kam- } \\
\text { Tao Li et al } \\
2003\end{array}$ & $\begin{array}{l}\text { Annals of internal } \\
\text { medicine }\end{array}$ & $\begin{array}{l}\text { Population : peritoneal dialysis } \\
\text { Mean age (range): } 59 \mathrm{y} \\
60 \text { patients }(\mathrm{G} 1=30, \mathrm{G} 2=30)\end{array}$ & G1: Ramipril & G2: Placebo & $5 \mathrm{mg}$ & 12 months \\
\hline $\begin{array}{l}\text { X Chen et al } \\
2006\end{array}$ & $\begin{array}{l}\text { Journal of } \\
\text { International } \\
\text { Medical Research }\end{array}$ & $\begin{array}{l}\text { Population : renal parenchymal hypertension } \\
\text { Mean age (range): } 18-70 \mathrm{y} \\
85 \text { patients }(\mathrm{G} 1=42, \mathrm{G} 2=43)\end{array}$ & G1: Benazepril & G2: Barnidipine & $20 \mathrm{mg}$ & 4 weeks \\
\hline $\begin{array}{l}\text { YU Li-tian et } \\
\text { al } 2011\end{array}$ & $\begin{array}{l}\text { Chinese Medical } \\
\text { Journal }\end{array}$ & $\begin{array}{l}\text { Population : hypertension with high risk of } \\
\text { cardiovascular event } \\
\text { Mean age (range): } 65.6 \mathrm{y} \\
1159 \text { patients }(\mathrm{G} 1=385, \mathrm{G} 2=390, \mathrm{G} 3=384)\end{array}$ & G1: Ramipril & $\begin{array}{l}\text { G2: Telmisartan } \\
\text { G3: Ramipril + Telmisartan }\end{array}$ & $10 \mathrm{mg}$ & 5 years \\
\hline
\end{tabular}




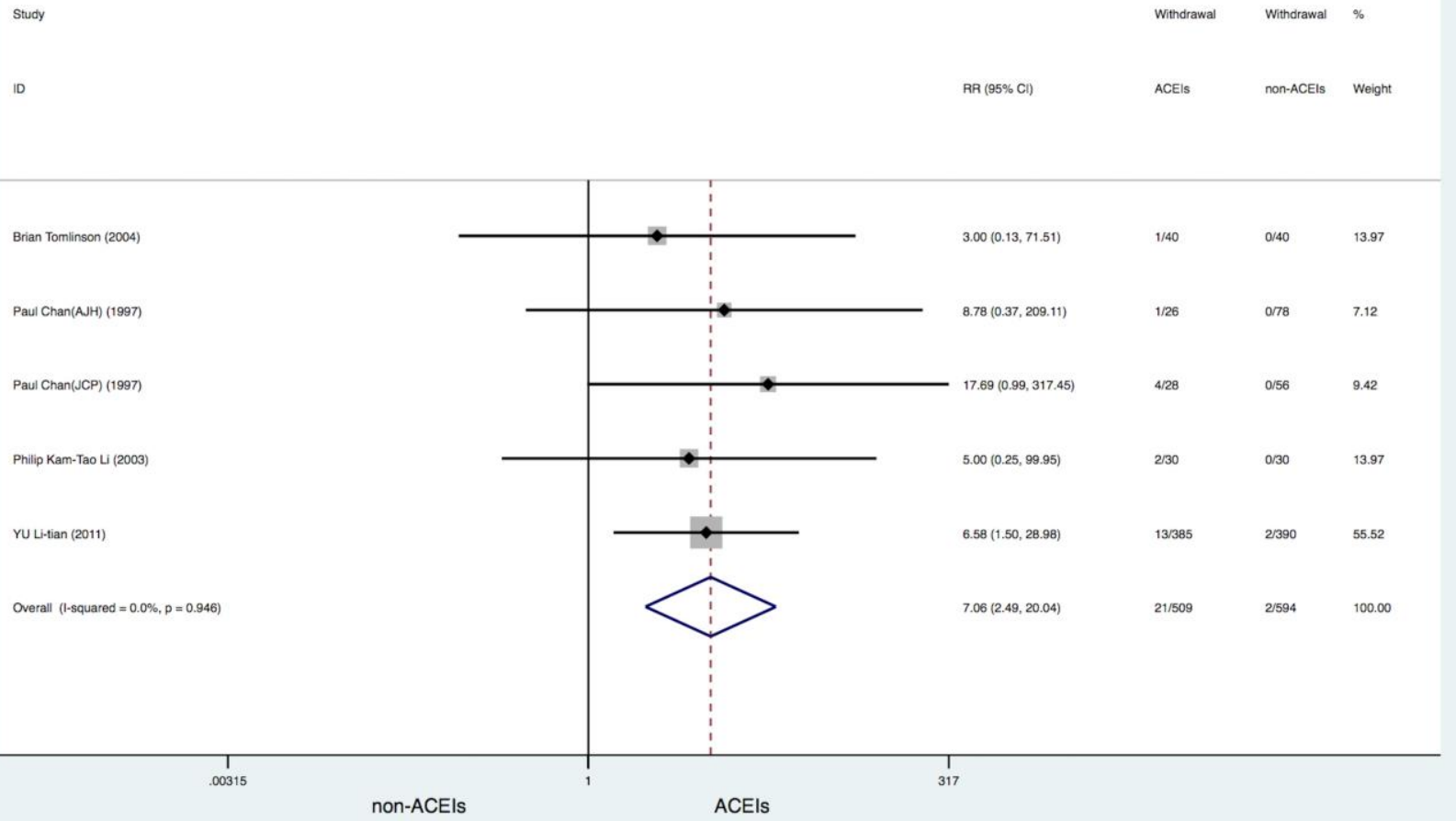

Figure 3. Relative risks of coughing between ACEI and non-ACEI

Study

ID

1 ACEls vs Placebo

Fan Fan Hou (2006)

Paul Chan(NH) (1997)

Philp Kam-Tao L (2003)

Subotata (1-squared $=0.0 \% 6, p=0.72$ )

${ }^{2}$ ACEls vs CCBS

Brian Tominson (2004)

Paul Chan(ANH) (1997)

$x$ Chen (2006)

Subsotal (1-squared $=38.7 \%, p=0.196$ )

${ }^{3}$ ACEIs vs ARBS

Chien-Hisun Hsia (2005)

Gary T. C. Ko (2005)

Kuan-Aau Chiou (2000)

Paul Chann(JCP) (1997)

YuLitan (2011)

1.Te Lee (2012)

Subcotal (1-squared $=0.0 \%, p=0.868)$

Overall (1-squared $=0.0 \%$, $p=0.805)$

$\prod_{.0037}^{1}$

Non-ACEls

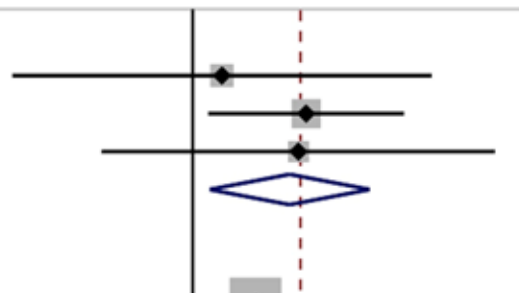

RR $(95 \% \mathrm{Cl}) \quad$ ACEls Non-ACEls Weight

$1.56(0.06,38.04) \quad 1 / 216 \quad 0 / 112 \quad 3.10$

$5.62(1.26,25.01) \quad 5 / 12 \quad 2 / 27 \quad 5.80$

$5.00(0.25,99.95) \quad 2230 \quad 0930 \quad 236$

$4.38(1.29,14.80) \quad 8258 \quad 2 / 69 \quad 11.26$

$2.60(1.02,6.61) \quad 13140 \quad 5 / 40 \quad 23.58$

$10.93(2.47,48.35) \quad 6 / 14 \quad 2 / 51 \quad 4.06$

$13.30(0.77,228.95) \quad 6 / 42 \quad 0 / 43 \quad 233$

$\begin{array}{llll}4.56(218,9.56) & 25.96 & 7 / 134 & 29.97\end{array}$

$2.78(0.12,65.08) \quad 1 / 26 \quad 0 / 24 \quad 2.45$

$16.43(1.00,270.41) \quad 7720 \quad$ ar2 $\quad 2.25$

$13.00(0.76,222.07) \quad 6 / 34 \quad 0 / 34 \quad 236$

$\begin{array}{llll}5.40(2.43,11.99) & 2728 & 5 / 28 & 23.58\end{array}$

$6.58(1.50,28.98) \quad 133385 \quad 2390 \quad 9.37$

$3.54(1.22,10.32) \quad 14.83 \quad 4 / 84 \quad 18.75$

$5.61(322,9.79) \quad 68578 \quad 11 / 582 \quad 58.76$

5.16 (3.39, 7.85) $\quad 101 / 930 \quad 201895 \quad 100.00$

Figure 4. The forest plot of withdrawal related to cough between ACEI and non-ACEI 


\section{DISCUSSION}

The eleven randomized controlled studies included in this meta-analysis provide a unique perspective on ACEI-induced cough in the Chinese population. Although there were many differences in the included trials, such as the participants' age and comparators used, the overall statistical heterogeneity of combined relative risk ratio was not observed. As a result, we did not analyze data based on the different comparators stratification. Previous studies indicated that different ethnic groups have different risks for developing adverse drug reactions, in particular to the cardiovascular drugs such as ACEI (14). In the present study, the incidence of ACEI induced cough in Chinese patients compared to non-ACEI cough was $11 \%$ and $2 \%$ respectively. A Cochrane review on ACEI compared to angiotensin enzyme receptor II blockers (ARB) in the treatment of primary hypertension showed that when compared with ACEI, ARB had about 2\% lower incidence in the discontinuation of drug due to cough (15). The relative risk ACE inhibitor induced cough was 2.7 (1.6 - 4.5) in East Asian compared to white patient. This meta-analysis included Chinese, Koreans, and Japanese as East Asians. No sub-analysis of Chinese population was included in the study. Vukadinovic et. al. completed a meta-analysis on the general population, and they found the relative risk for cough in patients treated with ACEI was 2.19 (95\% confidence interval (CI) 5 1.78-2.70, P $<0.0001$ ) vs. placebo (16). The ONTARGET study showed the ramipril group (an ACEI) had a higher treatment discontinuation due to cough as compared to telmisartan (an ARB) (4.2\% vs $1.1 \%$, $\mathrm{P}<0.001)$.(17) This current meta-analysis showed that Chinese patients treated with an ACEI were about five times more likely to develop cough compared to a non-ACEI. The dropout rate due to the cough in single ACEI treatment group was seven times the rate of the comparators treatment group.

The generally accepted mechanism of cough is that it is caused by bradykinin and substance $P$ which are degraded by ACE As a result, they are accumulated in the lungs when the ACE is inhibited (18). Both bradykinin and substance $\mathrm{P}$ sensitize the airway sensory nerves which induce cough (19-20). Evidence suggests that bradykinin receptor gene polymorphism is associated with ACEI-induced cough (21).

Only one study examined the difference in discontinuation rates in ACEI induce cough in Chinese compared with the general population (9). The results showed that Chinese are more than twice as likely to discontinue lisinopril (an ACEI) due to cough as the general population. Factors such as age, sex, co-morbidity and genetic polymorphisms, affect drug metabolism and drug responses including adverse effects.

A possible explanation for the increased incidence of cough in the Chinese is the presence of a genetic polymorphism predisposing to cough. Cytochrome P450 (CYP450) is the most common drug metabolism pathway. The CYP450 genotype is expressed differently in different ethnic groups (22). There are three groups of ACEI: captopril, prodrugs (Ramipril, enalapril), and lisinopril. With the exception of lisinopril, all ACEI molecules have a carboxyl functional group that requires carboxylase enzyme activation. Lisinopril is the only water-soluble ACEI that does not undergo hepatic metabolism. The SLCO1B1 gene is responsible in the hepatic metabolism of drugs including ACEI such as enalapril (23). An observational study with 450 Chinese patients conducted by Luo, et al., examined the association between SLCO1B1genetic polymorphisms and enalapril induced cough in a Chinese population (24). The results showed that patients with SLCO1B1 521C allele and SLCO1B1*15/*15 carriers are twice and seven times more likely to develop enalapril induced cough, respectively. Using the same patients from the previous observational study, Lou also showed there is an association between rs495828 polymorphism and enalapril induced cough (25). The role of genetic polymorphism in cough susceptible individuals warrants further exploration.

\section{Limitations}

All the included studies did not use a consistent tool to assess cough and the definition of cough related ACEI varied from one study to another. The observation periods were different in the included trials, which could lead to the different results of cough outcome since the cough occurrence rate increases in a longer observation time. Because none of the randomized control studies have been designed to directly compare the incidence of cough induced by ACEI between Chinese patients and other races, it is hard to draw a conclusion that the occurrence of cough side effect from ACEI in Chinese is higher and the discontinuation rate is higher than other races.

\section{CONCLUSION}

The incidence of medication induced cough in the Chinese population was $11 \%$ with ACEI medications and $2 \%$ for non-ACEI medications. The risk of developing ACEI induced cough was 5.16 (95\% CI: 3.39-7.85) times that of non-ACEI 
induced cough in this population. The dropout rate due to the intolerable cough in the single ACEI treatment group was 7.06 (95\%CI: 2.49-20.04) times that in the non-ACEI treatment.

\section{CONTRIBUTORS}

L.L. and H.L.B. conceived and conceptualized the research idea. J.K. conducted comprehensive searches. J.G., L.L. and H.L.B. reviewed the search, performed the screening, full text assessment. L.L. and H.L.B. did the quality assessment and data extraction. L.L. did data analyses, B.M. contributed and H.L.B. supervised the analysis. L.L. and H.L.B. framed the results and drafted the manuscript. A.C. and B.M. made revisions on the draft and approved the final version. L.L. supervised the whole study process and is guarantor.

\section{COMPETING INTERESTS}

The authors have no competing interests to declare.

\section{FUNDING}

This work did not receive any funding.

\section{DATA SHARING STATEMENT}

No additional data are available.

\section{REFERENCES}

1. Cardiovascular Diseases (CVDs). World Health Organization. https://www.who.int/en/news-room/factsheets/detail/cardiovascular-diseases-(cvds). Accessed September 30, 2019.

2. Staessen JA, Fagard R, Thijs L, et al; The Systolic Hypertension in Europe (Syst-Eur) Trial Investigators. Randomised double-blind comparison of placebo and active treatment for older patients with isolated systolic hypertension. Lancet. 1997;350:757-764. https://doi.org/10.1016/S01406736(97)05381-6

3. Beckett NS, Peters R, Fletcher AE, et al; HYVET Study Group. Treatment of hypertension in patients 80 years of age or older. N Engl J Med. 2008;358:1887-1898. DOI: $10.1056 /$ NEJMoa0801369

4. SHEP Cooperative Research Group. Prevention of stroke by antihypertensive drug treatment in older persons with isolated systolic hypertension: final results of the Systolic Hypertension in the Elderly Program
(SHEP).JAMA. 1991;265:3255- 3264. doi:10.1001/jama.1991.03460240051027

5. JATOS Study Group. Principal results of the Japanese trial to assess optimal systolic blood pressure in elderly hypertensive patients (JATOS). Hypertens Res. 2008;31:21152127. doi: 10.1291/hypres.31.2115.

6. Salvador GL, Marmentini VM, Cosmo WR, Junior EL. Angiotensin-converting enzyme inhibitors reduce mortality compared to angiotensin receptor blockers: Systematic review and meta-analysis. Eur J Prev Cardiol. 2017;24:1914-24.

\section{DOI: $\underline{10.1177 / 2047487317728766}$}

7. Verdecchia P, Staessen JA, Angeli F, et al; Cardio-Sis investigators. Usual versus tight control of systolic blood pressure in nondiabetic patients with hypertension (CardioSis): an open-label randomised trial. Lancet. 2009;374: 525-533. DOI: $10.1016 / \mathrm{S} 0140-$ 6736(09)61340-4

8. Dicpinigaitis PV. Angiotensin-converting enzyme inhibitor-induced cough: ACCP evidence-based clinical practice guidelines. Chest. 2006;129(suppl 1):169S-73S. doi: 10.1378/chest.129.1_suppl.169S. doi: 10.1378/chest.129.1_suppl.169S.

9. Tseng DS, Kwong J, Rezvani F, Coates AO. Angiotensin-converting enzyme-related cough among Chinese-Americans. Am J Med. 2010. 123:183. DOI: 10.1016/j.amjmed.2009.06.032

10. Chan WK, Chan TY, Luk WK, Leung VK, Li $\mathrm{TH}$, Critchley JA. A high incidence of cough in Chinese subjects treated with angiotensin converting enzyme inhibitors. Eur J Clin Pharmacol. 1993;44:299-300. DOI: $10.1007 / \mathrm{BF} 00271377$

11. Liberati A, Altman DG, Tetzlaff J, et al. The PRISMA Statement for Reporting Systematic Reviews and Meta-Analyses of Studies That Evaluate Health Care Interventions: Explanation and Elaboration. Vol 62.; 2009. doi:10.1016/j. jclinepi.2009.06.006. doi: $10.1186 / \mathrm{s} 13643-017-0663-8$

12. Higgins JPT, Green S, Cochrane Collaboration. Cochrane Handbook for Systematic Reviews of Interventions. WileyBlackwell; 2008. https://books. google. com/books?hl=en\&lr=\&id=NKMg9sMM6G UC\&oi=fnd\&pg $=$ PT13\&dq=cochrane + handb ook+for+systematic+reviews+of+interventio ns.+version+5.1.0\&ots=LIXIM0GGz7\&sig=I 6Mke-

ACzloMQTVPvny7FhnmjzI\#v=onepage\&q $\& \mathrm{f}=$ false. Accessed Sep- tember 10, 2019. 
13. Higgins JPT, Altman DG, Gøtzsche PC, et al. The Cochrane Collaboration's tool for assessing risk of bias in randomised trials. BMJ. 2011;343(7829):1-9. doi:10.1136/bmj.d5928.

14. Xie HG, Kim RB, Wood AJ, Stein CM. Molecular basis of ethnic differences in drug disposition and response. Ann Rev Pharmcol Toxicol. 2001;41:815-50. doi: 10.1146/annurev.pharmtox.41.1.815.

15. McDowell SE, Coleman JJ, Ferner RE. Systematic review and meta-analysis of ethnic difference in risks of adverse reactions to drugs used in cardiovascular medicine. BMJ. 2006;20:1177-81. doi: 10.1136/bmj.38803.528113.55.

16. Vukadinović D, Vukadinović AN, Lavall D, Laufs U, Wagenpfeil S, Böhm M. Rate of Cough During Treatment with angiotensinconverting enzyme inhibitors: A MetaAnalysis of Randomized Placebo-Controlled Trials. Clin Pharmacol Ther. 2019 Mar;105(3):652-660. doi: 10.1002/cpt.1018

17. Li EC, Heran BS, Wright JM. Angiotensin converting enzyme (ACE) inhibitors versus angiotensin receptor blockers for primary hypertension. Cochrane Database Syst Rev. 2014;22):CD009096. doi: 10.1002/14651858.CD009096.

18. ONTARGET Investigators, Yusuf S, Teo KK, Pogue J, Dya L, Copland I, et al. Telmisartan, ramipirl, or both in patients at high risk for vascular events. N Engl J Med. 2008358:1547-59 doi: 10.1056/NEJMoa0801317. Epub 2008 Mar 31.

19. Fox AJ, Lallo UG, Belvisi MG, et al. Bradykinin-evoked sensitization of airway sensory nerves: a mechanism for ACEinhibitor cough. Nat Med. 1996;2:814-7. doi: 10.1038/nm0796-814.

20. Mukae S, Aoki S, Itoh S, et al. Bradykinin B2 receptor gene polymorphism is associated with angiotensin-converting enzyme inhibitor-related cough. Hypertension. 2000;36:127-31.

doi: 10.1161/01.hyp.36.1.127.

21. Li YF, Zhu XM, Liu F, Xiao CS, Bain YF, Li $\mathrm{H}$, et al. Angiotensin-converting enzyme (ACE) gene insertion/deletion polymorphism and ACE inhibitor-related cough: a metaanalysis. PLoS One. 2012;7: e37396. doi: 10.1371/journal.pone.0037396.

22. McGraw J, Waller D. Cytochrome P450 variations in different ethnic populations. Wxpert Opin Drug Metab Toxicol.
2012;8:371-82. doi: 10.1517/17425255.2012.657626.

23. Liu L, Cui Y, Chung AY, Shitara Y, Sugiyama Y, Keppler D, et al. Vectorial transport of enalapril by Oatp1a1/Mrp2 and OATP1B1 and OATP1B3/MRP2 in rat and human livers. J Pharmacol Exp Ther. 2006;318:395-402. doi: 10.1124/jpet.106.103390.

24. Luo JQ, He FZ, Wang ZM, Sun NL, Wang LY, Tang GF, et al. SLCO1B1 variants and angiotensin converting enzyme inhibitor (enalapril)-induced cough: a pharmacogenetic study. Sci Rep. 2015;5:17253. doi: 10.1038/srep17253.

25. Luo JQ, He FZ, Lou ZY, Wen JG, Wang LY, Sun NL, et al. Rs495828 polymorphism of the ABO gene is a predictor of enalapril-induced cough in Chinese patients with essential hypertension. Pharmacogenetic Genomics. 2014; 24:306. doi: 10.1097/ FPC.000000000 0000050 . 
Supplementary Table.

\begin{tabular}{|c|c|}
\hline Database & Search Strategy \\
\hline $\begin{array}{l}\text { MEDLINE } \\
\text { Ovid } \\
\text { MEDLINE(R) } \\
\text { and Epub Ahead } \\
\text { of Print, In- } \\
\text { Process \& Other } \\
\text { Non-Indexed } \\
\text { Citations and } \\
\text { Daily 1946 to } \\
\text { February 14, } \\
2019\end{array}$ & $\begin{array}{l}\text { 1. exp Angiotensin-Converting Enzyme Inhibitors/ } \\
\text { 2. (ACE inhibitor* or angiotensin converting enzyme inhibitor*).mp. } \\
\text { 3. angiotensin converting enzyme antagonist*.mp. } \\
\text { 4. angiotensin converting enzyme blocker*.mp. } \\
\text { 5. dipeptidyl carboxypeptidase inhibitor*.mp. } \\
\text { 6. benazepril*.mp. } \\
\text { 7. Captopril/ or captopril.mp. } \\
\text { 8. cilazapril*.mp. or exp CILAZAPRIL/ } \\
\text { 9. exp Enalapril/ or enalapril*.mp. } \\
\text { 10. enalaprilat.mp. or exp ENALAPRILAT/ } \\
\text { 11. fosinopril*.mp. or exp FOSINOPRIL/ } \\
\text { 12. imidapril*.mp. } \\
\text { 13. exp LISINOPRIL/ or lisinopril.mp. } \\
\text { 14. moexipril*.mp. } \\
\text { 15. perindopril*.mp. or exp PERINDOPRIL/ } \\
\text { 16. quinapril*.mp. } \\
\text { 17. Ramipril/ or ramipril*.mp. } \\
\text { 18. saralasin.mp. or exp SARALASIN/ } \\
\text { 19. Teprotide.mp. or exp TEPROTIDE/ } \\
\text { 20. trandolapril*.mp. } \\
\text { 21. (alacepril or altiopril or ancovenin or ceranapril or ceronapril or deacetylalacepril or } \\
\text { delapril or epicaptopril or fasidotril* or foroxymithine or gemopatrilat or idrapril or } \\
\text { indolapril or libenzapril or moveltipril or omapatrilat or pentopril* or pivopril or } \\
\text { rentiapril or s nitrosocaptopril or spirapril* or temocapril* or utibapril* or zabicipril* or } \\
\text { zofenopril*).mp. } \\
\text { 22. or/1-21 } \\
\text { 23. Cough/ } \\
\text { 24. cough*.mp. } \\
\text { 25. exp Bronchial Spasm/ or (bronchospasm* or bronchial spasm*).mp. } \\
\text { 26. } 23 \text { or } 24 \text { or } 25 \\
\text { 27. Chinese.ti,ab,kf. } \\
\text { 28. China.ti,ab,kf. or exp CHINA/ } \\
\text { 29. Taiwan*.ti,ab,kf. or Taiwan/ } \\
\text { 30. (Hong Kong or Macao or Macau or Macanese).ti,ab,kf. } \\
\text { 31. Singapore*.ti,ab,kf. or Singapore/ } \\
\text { 32. or/27-31 } \\
\text { 33. } 22 \text { and } 26 \text { and } 32 \\
\text { 34. limit } 33 \text { to chinese } \\
\text { 35. limit } 33 \text { to english language } \\
\text { 36. } 34 \text { or } 35\end{array}$ \\
\hline $\begin{array}{l}\text { Embase } \\
\text { Embase } 1974 \text { to } \\
2019 \text { February } 14\end{array}$ & $\begin{array}{l}\text { 1. exp dipeptidyl carboxypeptidase inhibitor/ } \\
\text { 2. (ACE inhibitor* or angiotensin converting enzyme inhibitor*).mp. } \\
\text { 3. angiotensin converting enzyme antagonist*.mp. } \\
\text { 4. angiotensin converting enzyme blocker*.mp. } \\
\text { 5. dipeptidyl carboxypeptidase inhibitor*.mp. } \\
\text { 6. benazepril*.mp. } \\
\text { 7. captopril.mp. } \\
\text { 8. cilazapril*.mp. } \\
\text { 9. enalapril*.mp. } \\
\text { 10. enalaprilat.mp. } \\
\text { 11. fosinopril*.mp. } \\
\text { 12. imidapril*.mp. } \\
\text { 13. lisinopril.mp. } \\
\text { 14. moexipril*.mp. } \\
\text { 15. perindopril*.mp. }\end{array}$ \\
\hline
\end{tabular}




\begin{tabular}{|c|c|}
\hline & $\begin{array}{l}\text { 16. quinapril*.mp. } \\
\text { 17. ramipril*.mp. } \\
\text { 18. saralasin.mp. or exp saralasin/ } \\
\text { 19. Teprotide.mp. } \\
\text { 20. trandolapril*.mp. } \\
\text { 21. (alacepril or altiopril or ancovenin or ceranapril or ceronapril or deacetylalacepril or } \\
\text { delapril or epicaptopril or fasidotril* or foroxymithine or gemopatrilat or idrapril or } \\
\text { indolapril or libenzapril or moveltipril or omapatrilat or pentopril* or pivopril or } \\
\text { rentiapril or s nitrosocaptopril or spirapril* or temocapril* or utibapril* or zabicipril* or } \\
\text { zofenopril*).mp. } \\
\text { 22. or/1-21 } \\
\text { 23. exp coughing/ } \\
\text { 24. cough*.mp. } \\
\text { 25. exp bronchospasm/ or (bronchospasm* or bronchial spasm*).mp. } \\
\text { 26. } 23 \text { or } 24 \text { or } 25 \\
\text { 27. Chinese.ti,ab,kw. or Chinese/ } \\
\text { 28. China.ti,ab,kw. or exp China/ } \\
\text { 29. Taiwan*.ti,ab,kw. or Taiwan/ or Taiwanese/ } \\
\text { 30. (Hong Kong or Macao or Macau or Macanese).ti,ab,kw. } \\
\text { 31. Singapore*.ti,ab,kw. or Singapore/ or Singaporean/ } \\
\text { 32. or/27-31 } \\
\text { 33. } 22 \text { and } 26 \text { and } 32 \\
\text { 34. limit } 33 \text { to chinese } \\
\text { 35. limit } 33 \text { to english language } \\
\text { 36. } 34 \text { or } 35\end{array}$ \\
\hline CINAHL & $\begin{array}{ll}\text { S1 } & \text { (MH "Angiotensin-Converting Enzyme Inhibitors+") } \\
\text { S2 } & \text { "ACE inhibitor*" or "angiotensin converting enzyme inhibitor*" } \\
\text { S3 } & \text { "angiotensin converting enzyme antagonist*" } \\
\text { S4 } & \text { "angiotensin converting enzyme blocker*" } \\
\text { S5 } & \text { "dipeptidyl carboxypeptidase inhibitor*" } \\
\text { S6 } & \text { "benazepril*" } \\
\text { S7 } & \text { (MH "Captopril+") OR "captopril" } \\
\text { S8 } & \text { "cilazapril*" } \\
\text { S9 } & \text { (MH "Enalapril+") OR "enalapril*" } \\
\text { S10 } & \text { (MH "Enalaprilat") OR enalaprilat } \\
\text { S11 } & \text { (MH "Fosinopril") OR "fosinopril*" } \\
\text { S12 } & \text { "imidapril*" } \\
\text { S13 } & \text { (MH "Lisinopril+") OR "lisinopril" } \\
\text { S14 } & \text { "moexipril*" } \\
\text { S15 } & \text { (MH "Perindopril") OR "perindopril*" } \\
\text { S16 } & \text { "quinapril*" } \\
\text { S17 } & \text { "ramipril*" } \\
\text { S18 } & \text { "saralasin" } \\
\text { S19 } & \text { "Teprotide" } \\
\text { S20 } & \text { (MH "Trandolapril+") } \\
\text { S21 } & \text { alacepril or altiopril or ancovenin or ceranapril or ceronapril or deacetylalacepril } \\
\text { or delapril or epicaptopril or fasidotril* or foroxymithine or gemopatrilat or idrapril or } \\
\text { indolapril or libenzapril or moveltipril or omapatrilat or pentopril* or pivopril or } \\
\text { rentiapril or "s nitrosocaptopril" or spirapril* or temocapril* or utibapril* or zabicipril* } \\
\text { or zofenopril* } \\
\text { S22 S1 OR S2 OR S3 OR S4 OR S5 OR S6 OR S7 OR S8 OR S9 OR S10 OR S11 } \\
\text { OR S12 OR S13 OR S14 OR S15 OR S16 OR S17 OR S18 OR S19 OR S20 OR S21 } \\
\text { S23 } & \text { (MH "Cough") } \\
\text { S24 } & \text { cough* } \\
\text { S25 } & \text { (MH "Bronchial Spasm") } \\
\text { S26 } & \text { bronchospasm* or "bronchial spasm*" } \\
\text { S27 } & \text { S23 OR S24 OR S25 OR S26 } \\
\text { S28 } & \text { (MH "Chinese") OR "Chinese" }\end{array}$ \\
\hline
\end{tabular}




\begin{tabular}{|c|c|}
\hline & $\begin{array}{ll}\text { S29 } & \text { (MH "China+") OR "China" } \\
\text { S30 } & \text { (MH "Taiwan") or Taiwan* } \\
\text { S31 } & \text { (MH "Hong Kong") or "Hong Kong" } \\
\text { S32 } & \text { (MH "Macao") or Macao or Macau or Macanese } \\
\text { S33 } & \text { "Singapore*" } \\
\text { S34 } & \text { S28 OR S29 OR S30 OR S31 OR S32 OR S33 } \\
\text { S35 } & \text { S22 AND S27 AND S34 }\end{array}$ \\
\hline Scopus & $\begin{array}{l}\text { TITLE-ABS-KEY("ACE inhibitor*" OR "angiotensin converting enzyme inhibitor*" } \\
\text { OR "angiotensin converting enzyme antagonist*" OR "angiotensin converting enzyme } \\
\text { blocker*" OR "dipeptidyl carboxypeptidase inhibitor*" OR benazepril* OR captopril } \\
\text { OR cilazapril* OR enalapril* OR enalaprilat OR fosinopril* OR imidapril* OR } \\
\text { lisinopril OR moexipril* OR perindopril* OR quinapril* OR ramipril* OR saralasin OR } \\
\text { Teprotide OR trandolapril* OR alacepril or altiopril or ancovenin or ceranapril or } \\
\text { ceronapril or deacetylalacepril or delapril or epicaptopril or fasidotril* or foroxymithine } \\
\text { or gemopatrilat or idrapril or indolapril or libenzapril or moveltipril or omapatrilat or } \\
\text { pentopril* or pivopril or rentiapril or "s nitrosocaptopril" or spirapril* or temocapril* or } \\
\text { utibapril* or zabicipril* or zofenopril*) AND TITLE-ABS-KEY(cough* OR } \\
\text { bronchospasm* OR "bronchial spasm*") AND TITLE-ABS-KEY(Chinese OR China } \\
\text { OR Taiwan* OR "Hong Kong" OR Macao or Macau or Macanese OR Singapore*) } \\
\text { Limit to English, Chinese }\end{array}$ \\
\hline $\begin{array}{l}\text { ProQuest } \\
\text { Dissertations \& } \\
\text { Theses Global }\end{array}$ & $\begin{array}{l}\text { noft("ACE inhibitor*" OR "angiotensin converting enzyme inhibitor*" OR "angiotensin } \\
\text { converting enzyme antagonist*" OR "angiotensin converting enzyme blocker*" OR } \\
\text { "dipeptidyl carboxypeptidase inhibitor*" OR benazepril* OR captopril OR cilazapril* } \\
\text { OR enalapri* OR enalaprilat OR fosinopril* OR imidapril* OR lisinopril OR } \\
\text { moexipril* OR perindopril* OR quinapril* OR ramipril* OR saralasin OR Teprotide } \\
\text { OR trandolapril* OR alacepril or altiopril or ancovenin or ceranapril or ceronapril or } \\
\text { deacetylalacepril or delapril or epicaptopril or fasidotril* or foroxymithine or } \\
\text { gemopatrilat or idrapril or indolapril or libenzapril or moveltipril or omapatrilat or } \\
\text { pentopril* or pivopril or rentiapril or "s nitrosocaptopril" or spirapril* or temocapril* or } \\
\text { utibapril* or zabicipril* or zofenopril*) AND noft(cough* OR bronchospasm* OR } \\
\text { "bronchial spasm*") AND noft(Chinese OR China OR Taiwan* OR "Hong Kong" OR } \\
\text { Macao or Macau or Macanese OR Singapore*) }\end{array}$ \\
\hline Google Scholar & $\begin{array}{l}\text { (ACE inhibitors OR "angiotensin converting enzyme") AND cough AND (Chinese OR } \\
\text { China OR "Hong Kong" OR Macao OR Macau OR Taiwan OR Singapore) }\end{array}$ \\
\hline
\end{tabular}

